\section{UNIVERSITY \\ of DEBRECEN}

FACULTY OF

HEALTH

NYÍREGYHÁZA

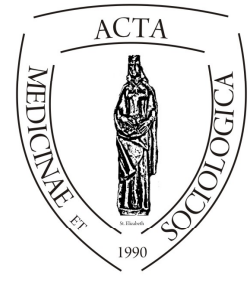

ACTA

MedSoc

VOLUME 3.

2013

\title{
Content of nitrogen oxide synthases in the mucosa of the stomach and duodenum of patients with NSAID gastropathy
}

\author{
Yu.M.Stepanov, Yu.S.Breslavets \\ Institute of Gastroenterology (Ukraine, Dnepropetrovsk)
}

\begin{abstract}
Content of nitrogen oxide synthases in the mucosa of the stomach and duodenum of patients with NSAID gastropathy.

The article presents results of immune histochemical investigation of the levels of inducible and endothelial nitric oxide synthases (iNOS and eNOS) in 120 patients with gastroduodenal inflammatory and erosive lesions of against the long-term use of nonsteroidal anti-inflammatory drugs (NSAIDs), and in 20 subjects without endoscopically verified gastrointestinal pathology, who comprised control group. The mean iNOS levels in patients with NSAIDs-gastropathies was $(2,30 \pm 0,09)$ and $(2,39 \pm 0,07)$ in patients of the first and second groups, in the control group - $(0,20 \pm 0,09)$ c.u; eNOS $-(2,10 \pm 0,09)$ and $(2,02 \pm 0,09)$ c.u. respectively, in the control group $(0,65 \pm 0,11)$. The direct correlation has been established between the levels of iNOS, eNOS and lesions of gastroduodenal mucosa at NSAID gastropathies $(p<0,001)$. These figures indicate the direct role of nitric oxide synthases in the chain of pathological reactions that develop in the stomach and duodenum of patients with NSAIDs - gastropathies.
\end{abstract}

Key words: NSAID gastropathy, nitrogen oxide synthases, immune-reactive reactions, acidproducing function of the stomach, H.pylori culture

DOI: $10.19055 / \mathrm{ams} .2013 .4 / 11 / 3$ 
Összefoglalás. Nitrogén-oxid szintáz érték a gyomor és a nyombél nyálkahártyájában NSAID-gastropathiás betegeknél

A cikkben immunhisztokémiai vizsgálat során kapott indukálható és endoteliális nitrogén-oxid szintáz (iNOS és eNOS) eredményeket mutattunk be 120 betegnél, akiknél gyulladásos, illetve eróziós gyomor és nyombél elváltozásokat állapítottunk meg huzamos nem szteroid gyulladáscsökkentő szerek (NSAID) szedése következtében és 20 személynél, akiknél endoszkópos vizsgálat során nem találtunk kóros elváltozást a tápcsatornában (a továbbiakban ők alkották a kontroll csoportot). Az átlag iNOS érték az NSAID-gastropathiás betegeknél $(2,30 \pm 0,09)$ és $(2,39 \pm 0,07)$ f.e. volt az első és a második megfigyelési csoportban, a kontroll csoportnál pedig $(0,20 \pm 0,09)$ f.e.; az eNOS érték - $(2,10 \pm 0,09)$ és $(2,02 \pm 0,09)$ f.e., illetve $(0,65 \pm 0,11)$ f.e. a kontroll csoportnál. Közvetlen összefüggést állapítottunk meg az iNOS, eNOS szint és a gasztroduodenális rendszer nyálkahártyájának kóros elváltozásai között NSAIDgastropathia esetén $(p<0,001)$. Ezek az adatok rámutatnak a nitrogén-oxid szintáz közvetlen szerepére ama kóros láncreakcióban, ami a gyomor és a nyombél nyálkahártyájában alakul ki NSAID-gastropathiás betegeknél.

Kulcsszavak: NSAID-gastropathia, nitrogén-oxid szintáza, immunreaktív válasz, a gyomor savtermelő funkciója, H.pylori kultúra

Among the factors which undeniably affect the development of inflammatory and destructive lesions of gastroduodenal zone, NSAIDs rank next to Helicobacter pylori (HP). Every drug is inherited with its biological and physicochemical properties, which are essentially a combination of both desirable as well as undesirable ones. Thus, extensive research activities are oriented towards the improvement of therapeutic efficacy of drugs through the removal of their undesirable effects. NSAIDs are among the most commonly prescribed classes of drugs throughout the world. Historically, the antiinflammatory drugs had their origin in the serendipitous discovery of certain plants and their extracts being applied for the relief of pain, fever and inflammation $[1,6,10]$.

Aspirin and NSAIDs have a storied history in the treatment of pain and rheumatic diseases. In the 4th century B.C., Hippocrates detailed the use of powder made from the bark and leaves of the willow tree (Salix spp.) for headache, pain, and fever. Ancient Egyptians and Assyrians also used a willow extract to relieve the pain and erythema of inflamed joints. In 1828, Johann Buchner at the University of Munich extracted and purified salicin from willow, and three decades later, Charles Gerhardt succeeded in synthesizing a "buffered" form of salicylate to reduce dyspepsia, acetylsalicylic acid. This synthetic compound, containing no willow derivatives, was marketed by Felix Hoffmann of the Bayer Company in 1899 as aspirin $[2,18]$. 
The importance and necessity of NSAIDs usage by patients with a marked pain syndrome, especially in pathology of locomotor apparatus was demonstrated by a series of investigations lasting from 6 to 18 months (such as MEDAL, CLASS, TARGET) [11, 20, 21]. Two large-scale studies comparing the adverse gastrointestinal effects of COX-2 specific inhibitors to those of traditional nonselective NSAIDs confirmed the relative safety of selective COX-2 inhibitors. The 2000 Vioxx Gastrointestinal Outcomes Research Trial (VIGOR) involved a randomized double-blind comparison of 8076 patients with rheumatoid arthritis. Participants received either 50mg of rofecoxib or 500mg of naproxen twice a day for nine months. The researchers found that significantly fewer adverse gastrointestinal events occurred in the rofecoxib treatment group. Furthermore, both medications showed similar efficacy against rheumatoid arthritis. A second study published in the same year also confirmed the relative gastrointestinal safety of selective COX-2 inhibitors, testing celecoxib. The Celecoxib Long-Term Arthritis Safety Study Trial (CLASS) involved 8059 patients with osteoarthritis or rheumatoid arthritis in a prospective, randomized double-blind comparison of three groups. Patients were assigned to receive either $400 \mathrm{mg}$ of celecoxib twice a day, $800 \mathrm{mg}$ of ibuprofen three times a day or $75 \mathrm{mg}$ of diclofenac twice a day. Celecoxib was found to be associated with fewer upper gastrointestinal side effects, including symptomatic ulcers and ulcer complications $[3,21]$.

The term "NSAID gastropathy" was established in 1986, in order to differentiate classic ulcerative diseases from the specific lesions of gastric mucosa. Large share of patients take these medicines to relieve pain. Nonsteroidal antiinflammatory drug associated gastropathy is a specific syndrome, associated with use of NSAIDs. This syndrome is expressed by mucosal lesions in gastric antrum and less frequently in the duodenum. The spectrum of NSAID-induced gastro-intestinal tract (GIT) pathology includes shallow mucosal changes, erosive gastritis, peptic ulcer disease, and ulcer complications, such as upper GIT bleeding, perforation, penetration, and obstruction. Dyspepsia occurs in 10-20\% of patients taking NSAIDs but also occurs frequently with non-NSAID analgesics, such as acetaminophen, and it is not predictive of ulcer development. Similarly, although two-thirds of patients taking NSAIDs have superficial mucosal lesions visible by endoscopy, these are not predictive of adverse outcomes. Recognition of frank ulcers, which represent $15-25 \%$ of patients with dyspepsia, is clinically important. The incidence of hospitalization for NSAID-related upper GIT bleeding is 1-2 \% per year and confers $5-10 \%$ mortality; although the overall annual mortality rate for GIT bleeding in this context is relatively low $(0.22 \%)$, the large number of patients with chronic NSAID exposure results in substantial morbidity and mortality. 
Unfortunately, many patients are poorly informed of the risks associated with this class of medications $[18,30]$.

The most often NSAIDs are used in pathology of osteo-muscular system, especially in case of osteoarthrosis. Over the period from 1997 till 2002 osteoarthrosis incidence in Ukraine doubled and continues to increase. By the data of the X-rays examinations, osteoarthrosis signs are revealed in $35 \%$ of persons younger than 30 years and almost in $100 \%$ over the age of 55 years. What is more, osteoarthrosis causes long-term disability and is responsible for about $10 \%$ of primary disablement of population $[5,16,28]$. The risk of complications from the side of gastro-intestinal tract in patients on NSAIDs medication increases. The lesions of gastroduodenal zone in the form of erosions is revealed in $10-29 \%$ of patients using NSAIDs. The most frequent pathologic changes are revealed in the antral portion of the stomach and more rarely in the bulb of the duodenum. NSAIDs cause the $20 \%$ of all side effects of drug therapy in England, $25 \%$ in the USA and over $40 \%$ in Ukraine; therewith $90 \%$ are gastroduodenal complications. Considering specificity of pathogenesis of pathologic process in NSAID gastropathies, complaints are absent in approximately $34 \%$ of the patients; this increases risk of complications in the form of gastro-intestinal bleedings [12, 28, 30].

According to modern medical data, there are multiple contributing factors in the development of NSAID gastropathy, which makes researchers continue studying its pathogenesis and contributing factors in detail. In accordance with pathogenesis of NSAID gastropathy it is supposed that there is no difference in complication risks depending on the routes of NSAIDs' administration (per os, or per rectum). There are several factors that increase the risk of peptic ulcer disease: age $>65$ years; past medical history of peptic ulcer disease; high doses of NSAIDs, or two NSAID drug combinations and/or long-term treatment regimens; co-treatment with corticosteroids; female gender; tobacco and alcohol; Helicobacter pylori infection. The clinical utility of an NSAID is determined by the compromise between its therapeutic efficacy and toxicity. If an NSAID is effective, but a patient cannot tolerate its side-effects then the NSAID is of no use to the patient. Safety is often a primary consideration in the choice of a particular NSAID. Given the apparent equivalent efficacy of NSAIDs it is not surprising that the promoted "safety" of an NSAID is a main determinant of its sales success. NSAID toxicity can be reduced by avoiding their use in high-risk patients, however, this is not always practical given that many such patients may require NSAIDs for daily functioning [18, 27].

NSAID gastropathy pathogenesis is not completely revealed, but it is deemed that these medications have ability to penetrate mucosal layer in the acid media of stomach; they damage bicarbonate barrier, cause back-diffusion of hydrogen ions into the gastric lumen and so with the direct contact cause damage. In the line with 
the up-to-day views, there exist some mechanisms of lesion of mucous membrane of the gastroduodenal zone when using drugs of this group. One of them is due to the blockade of cyclooxygenase-1 (COX-1) and disorder of synthesis of gastroprotective prostaglandins (PG) in the mucous membrane linked with. In 1972, John R. Vane demonstrated that aspirin blocks the synthesis of a proinflamatory cytokine, prostaglandin E, for which he was granted the Nobel Prize in 1982. Prostaglandin synthase (COX), the enzyme inhibited by aspirin, which converts arachidonic acid to prostaglandins, was discovered in 1989, and was found to have two isoforms: COX-1 and COX-2. The COX-1 enzyme is constitutively expressed in most cells of the body, and in the gastroduodenal mucosa the prostaglandins it produces serve to protect the mucosal lining from injury by luminal acid pepsin. COX-1 is also implicated in platelet aggregation (mediated by thromboxane A2) and maintenance of renal function. In contrast to COX-1, COX-2 expression is inducible by proinflamatory cytokines, and the products of its reaction are implicated in activation of the inflammatory cascade as well as the maintenance of renal function. Nonselective NSAIDs, such as aspirin, therefore reduce inflammation via COX-2 inhibition at the expense of platelet inhibition and GIT toxicity from COX-1 inhibition. COX-2 selective inhibitors then reduce inflammation without platelet inhibition or adverse GIT effects. As renal perfusion is affected by both enzymes, COX-2 selective inhibitors may still impart renal toxicity $[4,7,22,23,27]$.

The first COX-2 selective inhibitor, celecoxib (Celebrex), approved by the FDA in 1998 based upon the results of five clinical trials involving more than 5000 patients with degenerative or rheumatoid arthritis, showed comparable analgesia and efficacy to nonselective NSAIDs and placebo with fewer clinical and endoscopic gastroduodenal ulcers. Two other COX-2 selective inhibitors: valdecoxib and rofecoxib, were subsequently approved; however, in the wake of concerns of an increased risk of thromboembolic events, and with valdecoxib an additional risk of Stevens-Johnson syndrome, both were withdrawn from the U.S. market in 2005. Celecoxib remains available for the treatment of pain associated with degenerative joint disease and rheumatoid arthritis, but as of April 2005 carries a "black box" warning alerting consumers to the increased cardiovascular risk associated with this medication [18].

The relation between the infection with Helicobacter pylori and use of NSAIDs in the pathogenesis of peptic-ulcer disease is controversial, because studies examining these two risk factors in this disorder have had conflicting results. The conventional aspect is that the presence of both of these well-established risk factors for peptic-ulcer disease would be expected to increase the risk of the disease. However, this was not the case in several observational studies with patients taking NSAIDs, in which peptic-ulcer disease was less frequently diagnosed when HP infection was present than in patients without the infection. 
Conflicting results have also been reported from randomized controlled clinical trials on whether eradication of HP infection retards ulcer healing or reduces the risk of developing peptic-ulcer disease [8]. In the 4th Maastricht/Florence Consensus Conference, 44 experts from 24 countries took active part and examined key clinical aspects in three subdivided workshops: indications and contraindications for diagnosis and treatment, focusing on dyspepsia, non-steroidal anti-inflammatory drugs or aspirin use, gastro-oesophageal reflux disease and extraintestinal manifestations of the infection. A meta-analysis showed, however, that eradication seems less effective than treatment with maintaining PPI for preventing NSAID-associated ulcers [14, 15, 24].

At present there exist a lot of scientific publications devoted to the research into the role of this ferment in the pathogenesis of various diseases, NSAID gastropathies in particular. However, significantly less works are devoted to the role of nitrogen oxide (NO) in pathologic reactions, appearing in the case of gastroduodenal zone lesions, associated with the usage of non-steroid drugs.

In the 1980's researches linked with NO for the most part were devoted to the cardio-vascular system, however in the 1990's researches into the functional systems, gastroenterology in particular came under scrutiny. At present it is known, that NO impacts the state of smooth musculature, secretion of gastric juice, mucus production and alkaline metabolites [17, 26, 29].

Three basic types of isoenzyme of NO synthases, coded by various genes are distinguished by present day scientists: NOS1 (neuronal) and NOS3 (endothelial) are related to constitutive isoforms of synthases, their activity directly and proportionally depends on the increase of intercellular calcium; NOS2 (macrophageal) is an inducible form, practically not linked with calcium, it is activated under the impact of immunogenic and pro-inflammatory stimuli, and produced by 100.000 times more number as compared with constitutive forms. Under physiologic conditions NO appears as endogenous mediator of healing, restoration, tissue aggregation, i.e. it plays a protective role. Series of investigations, carried out by scientists of the USA and Russia, demonstrated the increase of NO synthases in the cells affected by pathologic process, of inducible isoform in particular in the case of pathology of gastroduodenal zone, caused by long-term usage of non-steroid drugs. However, in the recent years, questions like the uniqueness of positive impact of eNOS and negative impact of iNOS are being discussed. In a series of researches carried out in constitutive forms was established to stimulate cascade of pathologic changes, and NO produced in activation of iNOS, executes restorative function. At the same time, in the line with classic ideas, nitrogen oxide produced in iNOS increases pathologic changes typical for ulcerous process $[9,13,19,25]$. 
But despite a great interest and active study of the problem which investigates impact, they define optimal methods of its identification in the organs and tissues in various pathologies, in NSAID-gastropathies in particular.

\section{Aim of the research}

To study the content of nitric oxide synthases (eNOS and iNOS) in the mucosa of the gastroduodenal zone by immunohistochemical method in the case of NSAID gastropathies to compare with the persons of control group without endoscopically verified pathology of GIT, to assess interrelation between the level of content of nitric oxide synthases, selectivity of NSAID and H.pylori presence, and the level of acid-producing function of the stomach.

\section{Materials and methods of the research}

140 patients, of them 120 patients with inflammatory and erosive lesions of gastroduodenal zone (64 females and 56 males, aged from 18 to 67 years) in the main group, and 20 persons without endoscopically verified GIT pathology (7 females and 13 males, aged from 18 to 67 years) in the control group were under observation. In-patients and out-patients receiving NSAID as medication for a prolonged period of time (from 1 month to 3 years) were included into the research. In $93(77 \%)$ patients of the main group osteochondrosis and osteoarthrosis with the marked pain syndrome, including deforming one with disorder of functional degree (DFD) 2-3 stage was diagnosed, in 1 patient Bechterew's disease, in 12 patients - rheumatoid arthritis, and in 14 patients post-infarction cardiosclerosis. 82 patients $(68 \%)$ having complaints from the side of GIT underwent planned fibro-gastro-duodenoscopy (FGDS). Others 38 $(32 \%)$ patients without complaints up to the moment of examination noted periodical complaints in the anamnesis, which they linked with the onset of NSAID medication. These patients underwent FGDS, considering main diagnosis, presence of complaints in anamnesis and duration of NSAID medication. Depending on selectivity of NSAID all the patients were divided into 2 groups: patients of the 1st group (67 pts) received non-selective NSAIDs (aspirin, diclophenac), patients of the 2nd group (53 pts) received selective inhibitors of COX-2 (nimesulid, movalis). Patients both of the basic and control groups were of the same gender $(\mathrm{p}>0,40)$ and age $(\mathrm{p}>0,30)$.

State of the mucosa was evaluated after obtaining biopsy material. Endoscopic investigation was carried out by fiber-optic gastroscope PENTAX-FG-29; pH- 
metry was performed according to Chernobrovy's method. To perform morphologic investigation biopsy material of the patients obtained in FGDS was fixed in $10 \%$ solution of neutral buffered formalin during 10-12 hours with the aim to preserve integrity of cells and tissues. Later material was filled into paraffin in accordance with standards adopted. Paraffin thin-layer sections 3-5 mkm of thickness were stained with hematoxylin and eosin by standard techniques and were subjected to thorough microscopic investigation. To obtain sections, microtome with the station of receiving sections (Microm HM-340) was used. Light microscopic examination was performed by means of light microscope Leica DMLS using objectives $\mathrm{x} 10, \mathrm{x} 20, \mathrm{x} 40, \mathrm{x} 100$. Later, defining eNOS and iNOS content was carried out by immune-histochemical method, by the scale from 0 to 3, according to recommendations of Lazaraki G. et al. (2008). Thinlayered paraffin sections were incubated by antibodies in a damp chamber at temperature 23-250C during 30 minutes. Spectrum of antibodies, which included eNOS markers (endothelial synthase of nitric oxide, LabVision, USA), iNOS (inducible synthase of nitric oxide, LabVision, USA) were used as primary antibodies. Control investigations with the aim to exclude false-positive and false-negative results were used for every marker. Secondary antibodiesspecifically-selectively tropic ones to primary antibodies were applied on sections and incubated into damp chambers during 30 minutes with washing out between each stage during 10 minutes in TRIS-buffer solution. Immunohistochemical (IHC) investigation was carried out by using visualization system of the last generation UltraVision LP (LabVision, USA). Identification of reaction was carried out by applying diaminaminobenzydene chromogene (DAB) over the period from 20 seconds to 3 minutes under the control of microscope, with cytoplasma cells manifested in the form of dark-brown coloring. To differentiate tissue structures, sections additionally were stained with Mayer hematoxylin for 1-3 minutes. While performing IHC investigation, control sections with tissues, in which the above mentioned marker was revealed in all cases and in full measure were used to check up quality and specificity of reactions. Besides, as a quality control, reactions with unchanged intact epithelium were assessed. Qualitative and quantitative findings of the level of markers content were studied at a minimum 8-10 randomized chosen fields of vision of microscope of histologic sections at magnification $\mathrm{x} 400$ and $\mathrm{x} 1000$.

Assessment of eNOS and iNOS content was performed by the scale from 0 to 3 , in accordance with LAZARAKI G. et al (2008). Intensity was defined by criteria from 0 to 3 ( 0 for negative reaction, 1 for slight diffuse coloring, 2 for moderate granular coloring, 3 for intensive granular), and area - by percentage of colored cells to the whole area of the tissue $(<10 \%, 10-89 \%,>90 \%)$. So, aggregate finding $1(+)$ (intensity 1 , area $10-100 \%)$ of colored cells, or intensity 2-3 up to $10 \%$ of colored cells), $2(++)$ (in the range of intensity 2 and more than 
$10 \%$ of colored cells, to intensity 3 , with less than $90 \%$ of colored cells), and aggregate finding $3(+++)$ (intensity 3 and more than $90 \%$ of colored cells) were obtained.

Statistical processing of research materials was carried out using the program package Statistica ${ }^{\circledR}$ v.6.1. To assess authenticity of differences of mean values, criterion Student and Mann-Withney was used, for relative values - criterion of correspondence $\mathrm{Xi}$ - square (x2), correction of Yeits; to assess interrelation between separate signs - Spirmen's(r) coefficient of range correlation was used. Differences were considered as statistically significant in $\mathrm{p}<0,05$.

\section{Results and discussion}

The results of the endoscopical investigations in the basic groups of patients are the following: peptic ulcer of the stomach was revealed in 24 patients $(36,5 \%)$ of the 1 st group, and in 15 patients $(28,1 \%)$ in the 2 nd group; duodenal ulcer $13(19,1 \%)$ of the 1 st group and in $18(33,3 \%)$ - 2nd group; erosive gastritis in 22 patients $(34,9 \%)$ of the 1 st group, and in $15(28,1 \%)-2$ nd group. Unerosive mucosal changes was revealed in $9.5 \%$ of patients of the 1 st group and in $10,5 \%$ of patients in the 2 nd group (Fig. 1 ).

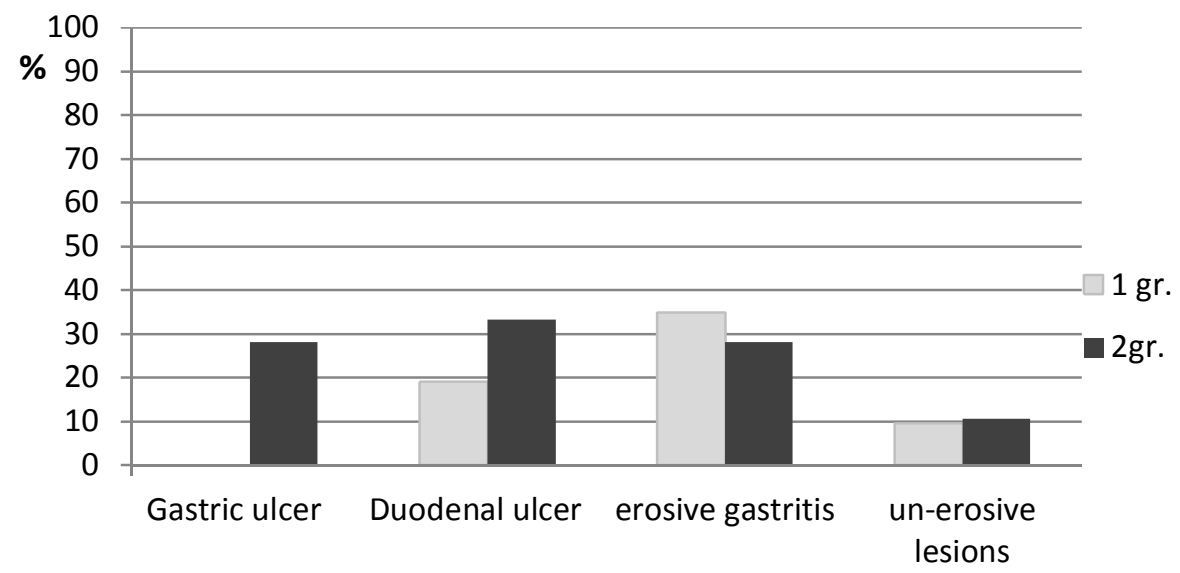

Fig 1. Structure of character of gastrodudenal zone lesion in dependence with NSAID selectivity 
Morphologic picture in the basic groups of patients did not differ significantly. Hyperplastic-atrophied gastritis with activity from $(+)$ to $(+++)$ was revealed in 60 patients $(90 \%)$ of the 1st group, and in $51(96 \%)$ - of patients in the 2 nd group ( $p>0,40)$, active hyperplastic gastritis - in $7(10 \%)$ of patients in the $1 \mathrm{st}$ group and in $2(4 \%)-2$ nd group.

Taking into account the importance of H.pylori presence in the ulcerogenic processes while performing quick urease test, in the groups of patients helicobacteriosis degree was revealed in comparison with the control group. Infectivity with H.pylori by the results of tests reached $61,9 \%(n=41)$ in the 1 st group, in the $2 \mathrm{nd}-73,7 \%(\mathrm{n}=39)$, in the control group $-50 \%(\mathrm{n}=10)$. Despite the absence of morphologically verified pathology of GIT in the patients of the control group, by the incidence of H.pylori revealing this group probably did not differ from other groups of investigation $(\mathrm{p}>0,20)$.

By the results of $\mathrm{pH}$-metry, increased $\mathrm{pH}$ level $(+)$ was revealed in $28(41,3$ $\%)$ of patients in the 1 st group and in 15 patients $(28,3 \%)$ in the 2 nd group $(\mathrm{p}<0,05), \mathrm{pH}(-)-$ in 30 patients $(44,4 \%)$ and in 23 patients $(43,4 \%)$ accordingly to the groups $(\mathrm{p}<0,05)$. $\mathrm{pH}(\mathrm{N})$ in 9 patients $(14,3 \%)$ in the 1 st group and in 15 patients $(28,3 \%)$ in the 2 nd group; in 10 persons $(50 \%)$ in the control group $\mathrm{pH}$ level complied with the norms ( $\mathrm{p}<0,001$ as compared to the 1 st and 2nd group). By the incidence of revealing of the increased $\mathrm{pH}$ level, patients of the control group were approaching to the patients of the 1st group $(\mathrm{p}>0,10)$ (Fig 2).

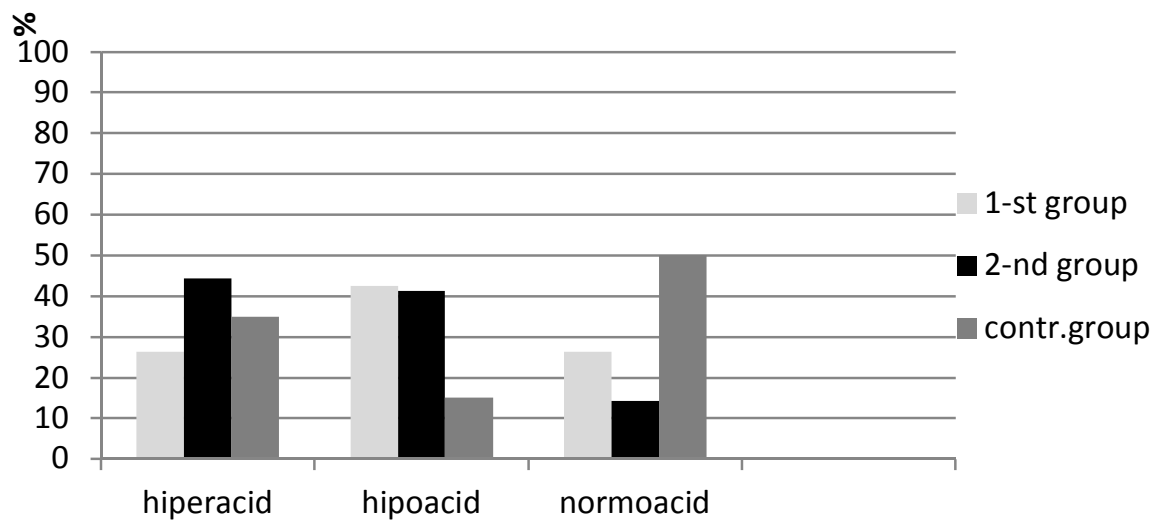

Fig 2. The results of pH-metry in dependence with NSAID selectivity 
Study of nitric oxide content in different groups of investigation showed the following: significant $(p<0,001)$ increase of iNOS content in the mucosa of gastroduodenal zone in case of inflammatory and erosive lesions of gastroduodenal zone, associated with a long-term usage of NSAIDs. It is important that enzyme acted directly in the cells of the gastroduodenal zone mucosa; this testifies to a high specificity of reaction (Fig. 3, Fig. 4).

Average level of iNOS $(\mathrm{M} \pm \mathrm{m})$ in patients of the I-st and II-nd group was $(2,30 \pm 0,09)$ and $(2,39 \pm 0,07)$ of conventional units (c.u.) correspondingly; this is more than 11 times exceeded analogous level in the patients of control group $(0,20 \pm 0,09)$ of c. u. (Fig.5). Probable differences between the level of inducible form of NO content, depending on selectivity of NSAIDs $(>0,40)$ used for a long-time period, were not revealed.

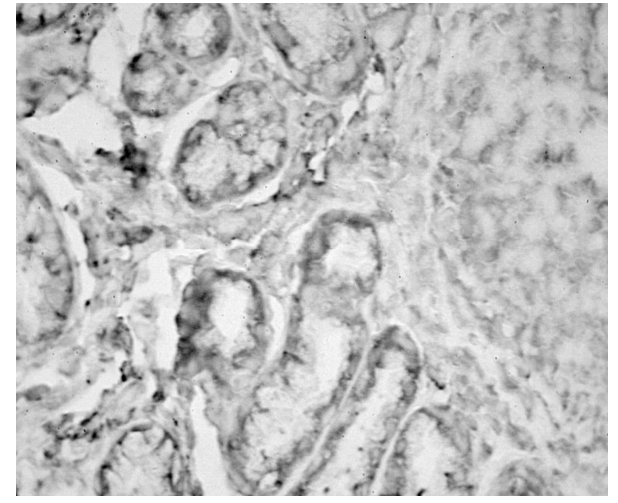

Fig.3. Bioptate of the antral portion of the stomach patient P., 26 years of age

NSAID gastropathy. Immuno-histochemical method with antibodies iNOS (endothelial synthase of nitric oxide LabVision, USA).

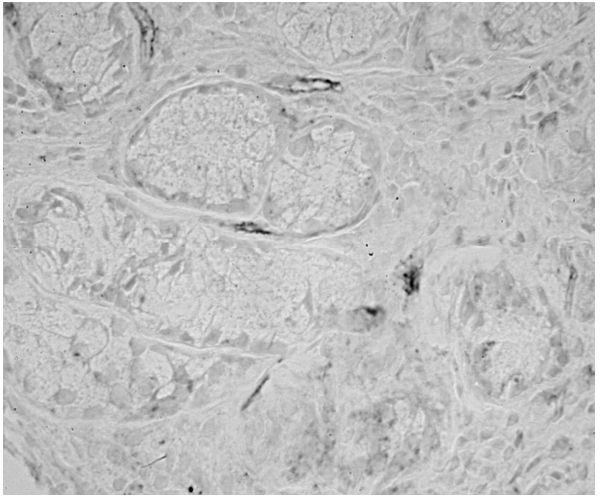

Fig. 4. Bioptate of the antral portion of the stomach, patient N., 20 years of age (control group). Immuno-histochemical method with antibodies iNOS (endothelial synthase of nitric oxide LabVision, USA).

As for eNOS production, its level was significantly higher as compared to the control one in patients of the 1 st group - $(2,10 \pm 0,09)$ against $(0,65 \pm 0,11)$ of c.u. $(\mathrm{p}<0,001)$, this level has a tendency to grow in patients of the 2 nd group $(2,02 \pm 0,09)$ of c. $u$. 


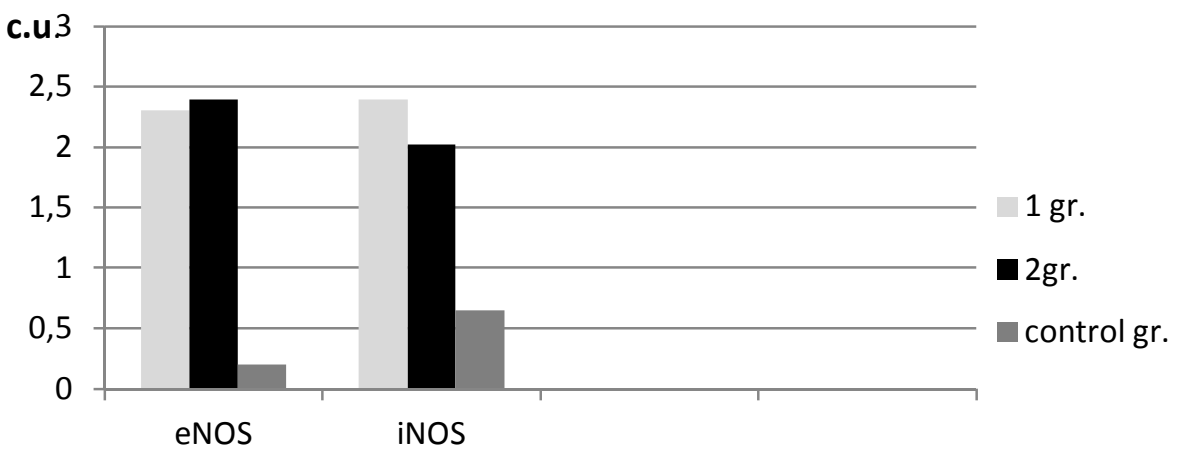

Fig.5 Mean levels of intensity of NO-synthases in patients with inflammatory and erosive lesions of the gastroduodenal zone: ${ }^{*}$ - $<0,001$ in comparison with control group.

$(p<0,007)$. Reaction was going on in the vessels located next to pathologic process, the latter testifies to non-specific reaction of the above mentioned marker in pathologic processes, especially in the mucosa of gastroduodenal zone (Fig.6, 7).

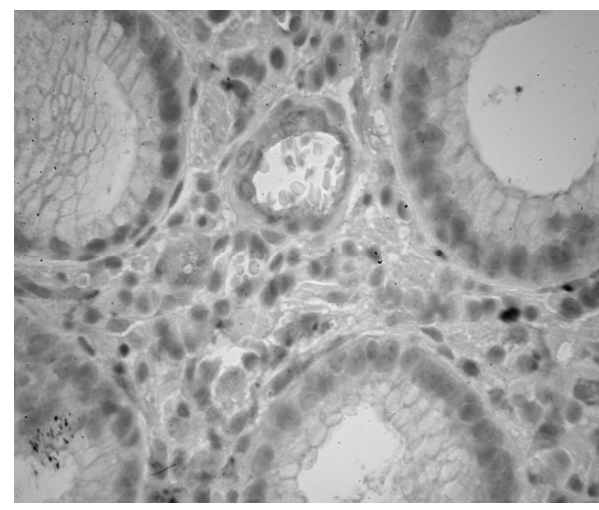

Fig.6. Bioptate of the antral portion of the stomach patient P., 26 years of age

NSAID gastropathy. Immuno-histochemical method with antibodies eNOS (endothelial synthase of nitric oxide LabVision,

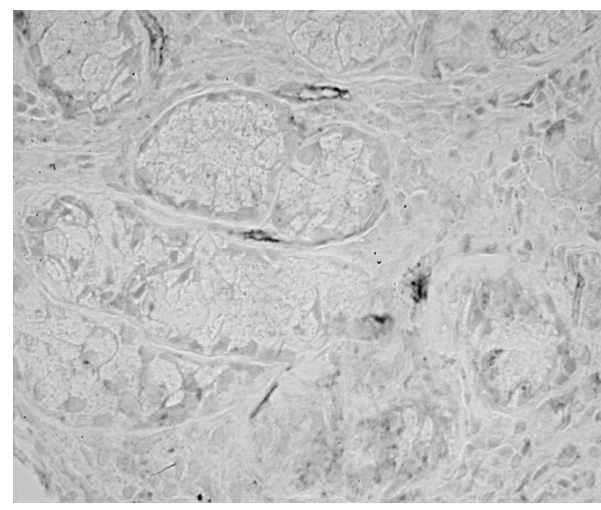

Fig.7. Bioptate of the antral portion of the stomach, patient N., 20 years of age (control group). Immuno-histochemical method with antibodies eNOS (endothelial synthase of nitric oxide LabVision, USA). 
So, the usage of non-steroid anti-inflammatory drugs over a prolonged period of time causes a cascade of pathologic reactions, stimulates synthesis of proinflammatory enzymes; which in turn significantly decreases protective properties of the gastroduodenal zone mucosa.

\section{Conclusions}

1. The increased level of iNOS and eNOS content in patients with NSAID gastropathies in comparison with persons without verified by means of endoscopic method pathology of GIT $(p<0,001)$ testifies to direct impact of NSAIDs usage on development of cascade of pathologic reactions in the mucosa of gastroduodenal zone.

2. The increase of immunoreactivity of iNOS in the cells affected by pathologic process testifies to specificity of the mentioned marker in inflammatory and destructive lesions of gastroduodenal zone on the background of NSADs medication.

3. In patients receiving non-selective non-steroid drugs, a tendency to increase the findings of acid-producing function of the stomach was noted, this is in inverse proportion as compared with patients, receiving selective NSAIDs $(\mathrm{p}<0,05)$.

4. Contamination with $H$. pylori in patients, receiving selective and nonselective NSAIDs significantly did not differ; this definitely may testify to the absence of a direct link between selectivity of non-steroid anti-inflammatory drugs and level of $\mathrm{H}$. pylori revealing.

\section{References}

1. Abnet C. C., Freedman N.D., Kamangar F. et al. (2009): Non-steroidal antiinflammatory drugs and risk of gastric and oesophageal adenocarcinomas: results from a cohort study and a meta-analysis. Br J Cancer 100(3): 551 557.

2. Appelboom T. (2002): Arthropathy in art and the history of pain management: through the centuries to the cyclooxygenase- 2 inhibitors. Rheumatology 41(suppl 1): 28-34.

3. Bombardier C., Laine L., Reicin A. et al. (2000): Comparison of upper gastrointestinal toxicity of rofecoxib and naproxen in patients with rheumatoid arthritis: VIGOR Study Group. Engl J Med. 343 (21): 1520-8. 
4. Buttgereit F., Burmester G., Simon L. (2001): Gastrointestinal toxic side effects of NSAID and cyclooxygenase-2 specific ingibitors. Am. J. Med. 110: $13-19$.

5. Chan F.K. (2010): Celecoxib versus omeprazole and diclofenac in patients with osteoarthritis and rheumatoid arthritis (CONDOR): a randomised trial. Ann Intern Med. Vol.376 (9736) 376: 173-179.

6. Hall A. J. (2003): Gastric mucosal cell model for estimating relative gastrointestinal toxicity of non-steroidal anti-inflammatory drugs. J Pharm Pharmacol. 55(5): 661.

7. Hinz. B., Cheremina O., Brune K. (2009): Acetaminophen (paracetamol) is a selective cyclooxygenase-2 inhibitor in man. The FASEB journal: Official publication of the Federation of American Societies for Experimental Biology 22 (2): 383-390.

8. Huang J., Sridhar S., Hunt R.H. (2002): Role of Helicobacter pylori infection and non-steroidal anti-inflammatory drugs in peptic-ulcer disease: a meta-analysis. Lancet 5: $15-16$.

9. Kubes P. (2004): Inducible nitric oxide synthase. Gut 51: 1234-1241.

10. Kumud M., Prodrugs M., Manishika Sh., Seema Th. (2011): Quest for Alternative to NSAIDs Gastropathy. International Journal of Research in Pharmaceutical and Biomedical Sciences 2(4): 1394.

11. Laine L. et. al. (2007): Assessment of upper gastrointestinal safety of etoricoxib and diclofenac in patients with osteoarthritis and rheumatoid arthritis in the Multinational Etoricoxib and Diclofenac Arthritis Long-term (MEDAL) programme: a randomized comparison. Lancet 9560 (369): 465473.

12. Laporte J., Ibanez L., Vidal X. (2010): Upper gastrointestinal bleeding associated with the use of NSAIDs. Drug. Saf. 27: 411-420.

13. Lazaraki G. at al. (2008): Helicobacter pylori infection upregulates endothelial nitric oxide synthase expression and induces angiogenesis in gastric mucosa of dyspeptic patients. European journal of gastroenterology \& hepatology 5: 441-449.

14. Malfertheiner P., Megraud F., O’Morain C. et al. (1997): European concepts in themanagement of helicobacter pylori infectionethe Maastricht consensus report. The European helicobacter pylori study group (EHPSG). Eur J Gastroenterol Hepatol. 9: 1-2.

15. Malfertheiner P., Megraud F., O'Morain C.A. et al. (2012): European Helicobacter Study Group. Management of Helicobacter pylori infection-the Maastricht IV/ Florence Consensus Report. Gut. 61(5): 646 - 664.

16. Orlando A. et al. (2009): Gastrointestinal lesions associayed with spondiloarthropathies. World Gastroenterol. 15 (20): 8. 
17. Shan V., Gores G. (2007): Nitric oxide in gastrointestinal health and disease. Gastroenterology 45: 787-781.

18. Schlansky B., Hwang J. (2009): Prevention of nonsteroidal anti-infl amatory drug-induced gastropathy. J Gastroenterol. 44 [Suppl XIX]: 44-52.

19. Schmidt H.H.H.W., Gagne G., Nacane M. et al. (1992): Mapping of neural nitric oxide synthase in the rat suggests frequent colocalisation with NADPH-diaphorase but not with soluble guanylyl cyclase, and novel paraneural function for nitrinergic signal transduction. Histochem. Cytochem. 40 (10): 1439 - 1456.

20. Schnitzer T.J., Burmester G.R., Mysler E. et al. (2004): Comparison of lumiracoxib with naproxen and ibuprofen in the Therapeutic Arthritis Research and Gastrointestinal Event Trial (TARGET), reduction in ulcer complications: randomised controlled trial. Lancet 364: 665-674.

21. Silverstein F.E., Faich G. et al. (2000): Gastrointestinal toxicity with celecoxib vs nonsteroidal anti-inflammatory drugs for osteoarthritis and rheumatoid arthritis: the CLASS study: a randomised controlled trial. Celecoxib Long-term Arthritis Study. JAMA 284 (10): 1247-1255.

22. Vane J.R. (1971): Inhibition of prostaglandin synthesis as a mechanism of action for aspirin-like drugs. Nat New Biol. 231: 232-5.

23. Vane J. R., Botting R., Botting J. (1996): Overview-mechanisms of action of antiinflammatory drugs. Improved non-steroidal anti-inflammatory drugs. COX-2 enzyme inhibitors. Kluwer Academic Publishers 1-27.

24. Vergara M., Catalan M., Gisbert J.P. et al. (2005): Meta-analysis: role of Helicobacter pylori eradication in the prevention of peptic ulcer in NSAID users. Aliment Pharmacol. Therapi 21: 1411-18.

25. Yang W.D., Ando J., Korenaga R. et al. (1994): Exogenous nitric oxide inhibits proliferation of cultured vascular endothelial cells. Biocemestry immunications 203(2): $1160-1167$.

26. Ивашкин В.Т., Драпкина О.М. (2000): Оксид азота в регуляции функциональной активности физиологических систем. Росс. Журнал гастроэнтерологии, гепатологии, колопроктологии 4: 16 - 21 .

27. Игнатова Ю.Д., Кукеса В.Г., Мазурова В.И. (2010): Клиническая фармакология нестероидных противовоспалительных средств Москва, ГЭОТАР_Медиа С. 5,7.

28. Козлова И.В., Липатова Т.Е., Афонина Н.Г., Кветной И.М. (2006): Гастропатия, индуцированная НПВС, у больных остеартрозом: роль некоторых факторов диффузной эндокринной системы желудка в ее возникновении. Росийский журнал гастроэнтерологии, гепатологии, колопроктологии 1: $47-52$. 
29. Малышев И.Ю. (1997): Введение в биохимию оксида азота: Роль оксида азота в регуляции основных систем организма. Рос.жур. гастроэнтерологии, гепатологии, колопроктологии 1: 49 - 55.

30. Насонов Е.Л. (2009): Применение нестероидных противовоспалительных препаратов: клинические рекомендации, Москва, ИМА-ПРЕСС 5-23

\section{Yu.M.Stepanov, Yu.S.Breslavets}

Institute of Gastroenterology

49074, Ukraine, Dnepropetrovsk, Pravda avenue, 96 